\title{
Preliminary study of the monoterpene response of three pines to Ophiostoma clavigerum (Ascomycetes : Ophiostomatales) and two chemical elicitors
}

\author{
F Lieutier 1, AA Berryman 2, JA Millstein 2 \\ ${ }^{1}$ INRA, Ardon 45160 Olivet, France; \\ 2 Washington State University, Department of Entomology, Pullman, WA 99164, USA
}

(Received 3 August 1990; accepted 15 March 1991)

\begin{abstract}
Summary - The monoterpene response of phloem and sapwood of individual pines belonging to 3 species (Pinus contorta, Pinus ponderosa and Pinus monticola) to inoculation with Ophiostoma clavigerum and injection with chitosan, a proteinase inhibitor-inducing factor and a control buffer, was investigated quantitatively and qualitatively. The total quantity of monoterpene in the reactive tissues increased with each treatment but to different levels. In each tree, the monoterpene composition of the reactive tissues differed from that of the unwounded tissues, but was the same whatever the treatment, even in the case of an injection with buffer control. In addition, phloem and sapwood responses were qualitatively identical although constitutive compositions differed greatly. The composition of reactive tissues was not very different from that of unwounded sapwood. The direction of variation of each monoterpene from unwounded to reactive tissues differed according to the particular tree. Only phellandrene + limonene reacted consistently. From these results we cannot conclude that chitosan is a natural elicitor, and the non-specificity of the response for the aggression favors the hypothesis that an elicitor originates from the tree itself. Because of this non-specificity, and the fact that the three trees responded in a qualitatively different manner, we suggest that the qualitative monoterpene response of the tree is not adapted to any specific aggressor even though these trees are usually hosts of the same bark beetle-fungus complex. Thus, the role of monoterpenes in the induced defensive response is very likely a quantitative and dose-dependent relationship.
\end{abstract}

monoterpenes / Pinus contorta / Pinus ponderosa / Pinus monticola / Ophiostoma clavigerum / chemical elicitors / defense reaction / gas chromatography

Résumé - Étude préliminaire de la réponse monoterpénique de trois pins à Ophiostoma clavigerum (Ascomycètes: Ophiostomatales) et à deux éliciteurs chimiques. La réponse monoterpénique du phloème et de l'aubier de 3 arbres appartenant aux espèces Pinus contorta, Pinus ponderosa et Pinus monticola a été étudiée d'un point de vue quantitatif et qualitatif, après des inoculations du champignon $O$ clavigerum et des injections de chitosane, d'un facteur induisant une inhibition de protéinase (PIIF) et d'une solution tampon témoin. La quantité totale de monoterpènes (hydrocarbures) mesurée après 3,7 ou $14 j$ dans les tissus réactionnels augmente après chaque traitement, mais atteint des niveaux différents, le plus élevé étant obtenu après inoculations du champignon. Dans le cas du chitosane, la réponse est quantitativement proche de celle dirigée contre $\mathrm{O}$ clavigerum chez $\mathrm{P}$ ponderosa, mais ne diffère pas de celle dirigée contre le PlIF et la solution tampon chez les 2 autres arbres (tableau I). Dans chaque arbre, la composition monoterpénique des tissus réactionnels diffère de celle des tissus non altérés, mais s'avère semblable quel que soit 
le traitement, même avec les inoculations de tampon témoin (tableau l/ et fig 1). De plus, les réponses du phloème et de l'aubier sont qualitativement identiques, bien que leur composition initiale soit très différente. La composition des tissus réactionnels n'est en outre pas très différente de celle do l'aubier inaltéré (fig 1). Le sens de variation de chaque monoterpène entre le tissu inaltéré et le tissu réactionnel varie selon l'arbre considéré; seul le groupe phéllandrène + limonène réagit toujours dans le même sens (fig 2).

II n'est pas possible de conclure de ces résultats que le chitosane est un éliciteur naturel, et la nonspécificité de la réponse vis-à-vis de l'agresseur est en faveur d'une hypothèse qui situerait dans l'arbre lui-même l'origine de l'éliciteur. À cause de la non-spécificité de la réponse et du fait que less 3 arbres réagissent différemment d'un point de vue qualitatif, il est suggéré que la réponse monoterpénique qualitative d'un arbre n'est pas adaptée à un agresseur particulier, bien que ces arbres soient des hôtes habituels du même couple scolytide-champignon. Ainsi, le rôle des monoterpènes dans la réaction de défense induite est très probablement de nature quantitative et dépendrait de la dose accumulée.

monoterpène / Pinus contorta / Pinus ponderosa / Pinus monticola / Ophiostoma clavigerum / éliciteur chimique / réaction de défense / chromatographie en phase gazeuse

\section{INTRODUCTION}

The fungus Ophiostoma clavigerum (Robinson-Jeffrey and Davidson) Upadhyay plays a decisive role in the mechanisms of establishment of the bark beetle Dendroctonus ponderosae Hopk in North American pines, particularly Pinus contorta var latifolia Engelmann, Pinus ponderosa Lawson and Pinus monticola Douglas (Reid et al, 1967; Safranyik et al, 1975; Shrimpton, 1978; Raffa and Berryman, 1983). During bark beetle attacks, this fungus stimulates host parenchymal cells to produce resin which impregnates the tissues located around the site of attack (Reid et al, 1967; Berryman, 1969; Lieutier and Berryman, 1988). This induced reaction is the main line of tree defense against the attack of the bark beetle and its associated fungus. However, the nature and the origin of the chemical elicitor responsible for the stimulation of the parenchyma cells is not clear.

In a previous paper, we reported the histological changes induced in the reactive tissues of these 3 pine species by artificial inoculations of $O$ clavigerum and injections of 2 chemical elicitors, chitosan and a proteinase inhibitor-inducing factor (PIIF) (Lieutier and Berryman, 1988). Here we demonstrate both qualitative and quantitative changes in monoterpenes induced in the same tissues by the same inoculations and injections. Note that chitosan is a mixture of $\beta-(1,4)$ glucosamine polymers which are constituents of arthropod integuments and of most fungal cell walls (Hadwiger and Beckman, 1980). PIIF is composed of pectic oligomeric fragments derived from plant cell walls, the most active being $\alpha-(1,4)$ galacturonic acid polymers and oligomers (Ryan et al, 1985). Both chitosan and PIIF are possible elicitors of induced responses in plants naturally attacked by insects and fungi (Hadwiger et al, 1981; Walkers-Simons et al, 1984; Green and Ryan, 1972).

Quantitative and qualitative monoterpene modifications in response to the attack of bark beetles and associated fungi have been reported in conifers by several authors. Shrimpton (1973), Raffa and Berryman (1982a), Schuck (1982) and Delorme and Lieutier (1990) noted an increase of the total monoterpene content of phloem and sapwood in the induced reactions of $P$ contorta, Abies grandis (Lindley), 
Picea abies Karst and Pinus sylvestris L, respectively. Miller et al (1986) reported a greater increase in the total monoterpene content of Lodgepole pine phloem in response to chitosan than to either PIIF or $O$ clavigerum. Qualitative changes in the monoterpene fraction of the phloem were observed by Russel and Berryman (1976) and Raffa and Berryman (1982a) in $A$ grandis, by Raffa and Berryman (1982b) in $P$ contorta, by Cook and Hain (1985) in Pinus taeda $L$ and by Delorme and Lieutier (1990) in P sylvestris. In the last 2 cases, the qualitative changes were the same for a given tree for all treatments (ie, 2 different strains of the same fungus in $P$ taeda, 3 different fungus species and 1 beetle in $P$ sylvestris). Shrimpton (1973) was unable to observe any qualitative changes in $P$ contorta sapwood, with the exception of $\beta$ phellandrene after natural attacks by $D$ ponderosae. However, Schuck (1982) reported changes in some monoterpene components of $P$ abies sapwood after wounding.

\section{MATERIALS AND METHODS}

The experimental devices and techniques were previously described by Lieutier and Berryman (1988). One specimen of each tree species ( $P$ contorta, $P$ ponderosa, $P$ monticola $\approx 30 \mathrm{~cm}$ diameter breast height from an even-aged mixed conifer stand) received a total of 12 inoculations (4 treatments replicated thrice) in July 1985 at breast height using the cork-borer technique (Wright, 1933; Wong and Berrryman, 1977). The first treatment was inoculation with $O$ clavigerum, the second with chitosan, and the third with PIIF. Fungal cultures were 10-15 d old. The chemical solutions consisted of a nitrous acid cleaved crab shell chitosan and a raw PIIF extract from tomato plants dissolved in 0.05 $M$ sterile phosphate buffer $(\mathrm{pH} 7)$ at the rate of 1 $\mathrm{mg} / \mathrm{ml}$. The fourth treatment was an injection of the sterile buffer alone. All inoculations consisted of $100 \mu \mathrm{l}$ of chemical solution or a $5-\mathrm{mm}$ plug of agar containing fungal mycelia. On each sampling occasion ( 3,7 and $14 \mathrm{~d}$ after treatments), one sample of each treatment was taken on each tree. Reactive phloem (with cambium) and sapwood were removed and cut longitudinally in half. One half was immersed in a cupric acetate solution for histological observations (Lieutier and Berryman, 1988) and the other was immediatly placed on dry-ice and stored at $-60^{\circ} \mathrm{C}$. Two wk after treatment, samples of unwounded phloem and sapwood were also collected and stored in the same manner.

Monoterpene analyses were performed on samples collected after 3 and $14 \mathrm{~d}$. Samples collected $14 \mathrm{~d}$ aftei treatment were divided into 3 $20-\mathrm{mm}$ pieces, starting at the point of inoculation and working away from the wound, giving sub-samples at 0-20 mm, 20-40 mm, and 40$60 \mathrm{~mm}$ Three-d-old samples consisted of a single 0-20 mm piece. Each phloem sub-sample was finely chopped and then shaken in $10 \mathrm{ml}$ pentane for $24 \mathrm{~h}$. The extracts were filtered by flash chromatography in silica-gel $G$ which was rinsed thrice in pentane. They were concentrated under a stream of nitrogen to $0.5,1$ or $2 \mathrm{ml}$ according to the richness in total monoterpenes. Analyses were performed on a Perkin-Elmer Sigma-3 gas chromatograph equipped with a flame ionization detector and a $30 \mathrm{~m} \times 0.2 \mathrm{~mm}$ capillary column (Supelco SE-30). The carrier gas was helium at $1.1 \mathrm{ml} / \mathrm{min}$ at $18 \mathrm{psi}$. The column temperature program was $80^{\circ} \mathrm{C}$ for $14 \mathrm{~min}$, a rise of $20^{\circ}$ per min to $100^{\circ} \mathrm{C}$, then $100^{\circ} \mathrm{C}$ for $40 \mathrm{~min}$. The injector and detector temperatures were constant at $250^{\circ} \mathrm{C}$. Three replicates were performed for each sub-sample. Peaks were identified by comparison with the retention times of pure monoterpenes added to the samples and by enhancement after these additions. For $P$ contorta, comparisons were also made with mass spectrography results from Raffa and Berryman (1982b). The quantitative values were determined by means of an electronic digital integrator using p-cymene as an internal standard (this terpene was found to be lacking in preliminary chromatograms).

The monoterpene compositions of the samples were compared by principal component analysis (PCA), for each tree separately, and considering only monoterpenes which were present at levels of $0.5 \%$ or greater in each sample. This analysis was carried out with SAS software (SAS institute).

In the present study, each tree species was represented by only one individual. However, our aim was not to define the qualitative re- 
sponse of these species but rather to compare the terpene composition of responding tissues with that of unwounded tissues of the same tree. Although there is a great deal of variation in the monoterpene composition of conifer species (see, for example, Cates and Alexander, 1982), variations between species are much greater to the extent that they can be used as taxonomic characteristics (Zavarin et al, 1977). Our study was designed to examine the extremes of variability in the defensive reaction to a pathogen and 2 elicitors.

\section{RESULTS}

As the extracts were filtered on silica gel, oxygenated compounds were probably lost from the samples. Thus, in the following, the word "total monoterpene" refers only to hydrocarbides which in fact correspond to most of the monoterpene compounds.

Concentrations of total monoterpenes (hydrocarbides) in the different phloem and sapwood samples are presented in table I. As we have only 1 tree per species, between-tree comparison of absolute values is not possible. We therefore compare values between treatments within trees. O clavigerum generally induced a higher accumulation of monoterpenes than the chemical treatments. In $P$ ponderosa however, the quantitative response to chitosan was often close to the response to the fungus. The terpene accumulations induced by PIIF and buffer alone were always less than that induced by the fungus. They were also less than that induced by chitosan in $P$ ponderosa (phloem and sapwood, $14 \mathrm{~d}$ after injury) and in the phloem of $P$ monticola.

Seventeen different peaks (not always present) were obtained by gas chromatography when reactions were compared with unwounded tissue. One peak was heptane, 12 were monoterpenes, and 4 (probably monoterpenes) unidentified peaks were labelled $\mathrm{T} 1$ to $\mathrm{T} 4 . \quad \beta$ phellandrene and limonene made up a single peak, but $P$ contorta contains mainly $\beta$ phellandrene (Raffa and Berryman, 1982b; Smith, 1983) and $P$ ponderosa mainly limonene (Smith, 1966). As an example, table II gives the monoterpene percentages for the response of the trees to fungus after $14 \mathrm{~d}$ in comparison with unwounded tissues. In this table, some major differences can be noticed between reactive and unwounded tissue. Figure 1 allows a general qualitative comparison between treatments, dates, tissues, and distance from the inoculation point for each tree.

The first axis of the PCA (fig 1) explained $58.6,72.5$ and $55.6 \%$, the second axis $20.8,13.1$ and $21.8 \%$ and the third axis $7.2,6.9$ and $9.9 \%$ of the variability, respectively in $P$ contorta, $P$ ponderosa and $P$ monticola. The first axis compared unwounded phloem to reactive tissues and can be called the reaction axis. In $P$ ponderosa and $P$ monticola, the second axis, with the first, separated unwounded sapwood from reactive tissues. In $P$ contorta, unwounded sapwood was separated from reactive tissues by the third axis. Thus, 3 main types of monoterpene composition were identified: unwounded phloem, unwounded sapwood, reactive tissues (phloem and sapwood together) (fig 1; table II).

In all trees and in all 3 axes, reactive phloem could not be separated from reactive sapwood. In addition, the composition of reactive tissue did not appear very different from that of unwounded sapwood, with only small differences occurring in the concentration of some monoterpenes (table II). The changes in phloem composition induced by treatments are summarized in figure 2 , the response to fungus inoculation after $14 \mathrm{~d}$ being chosen as being representative of all treatments (cf, fig 1). Monoterpene fractions changed differently 


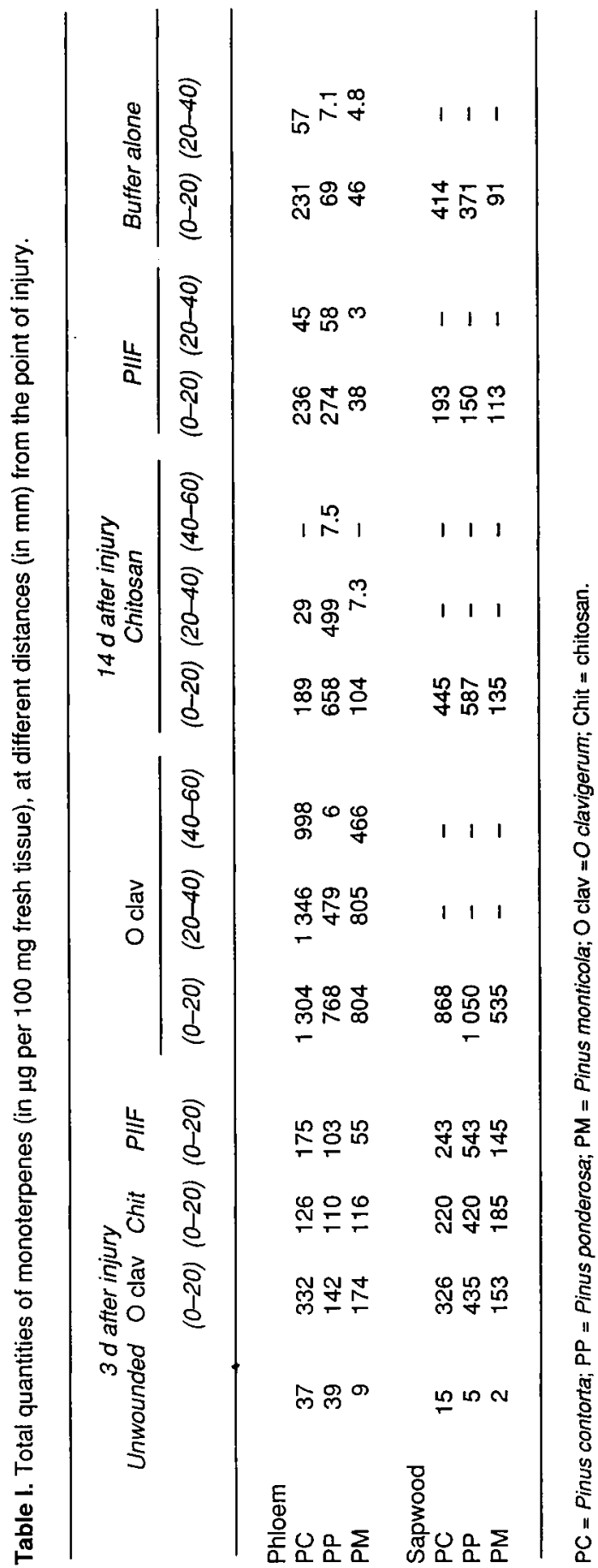




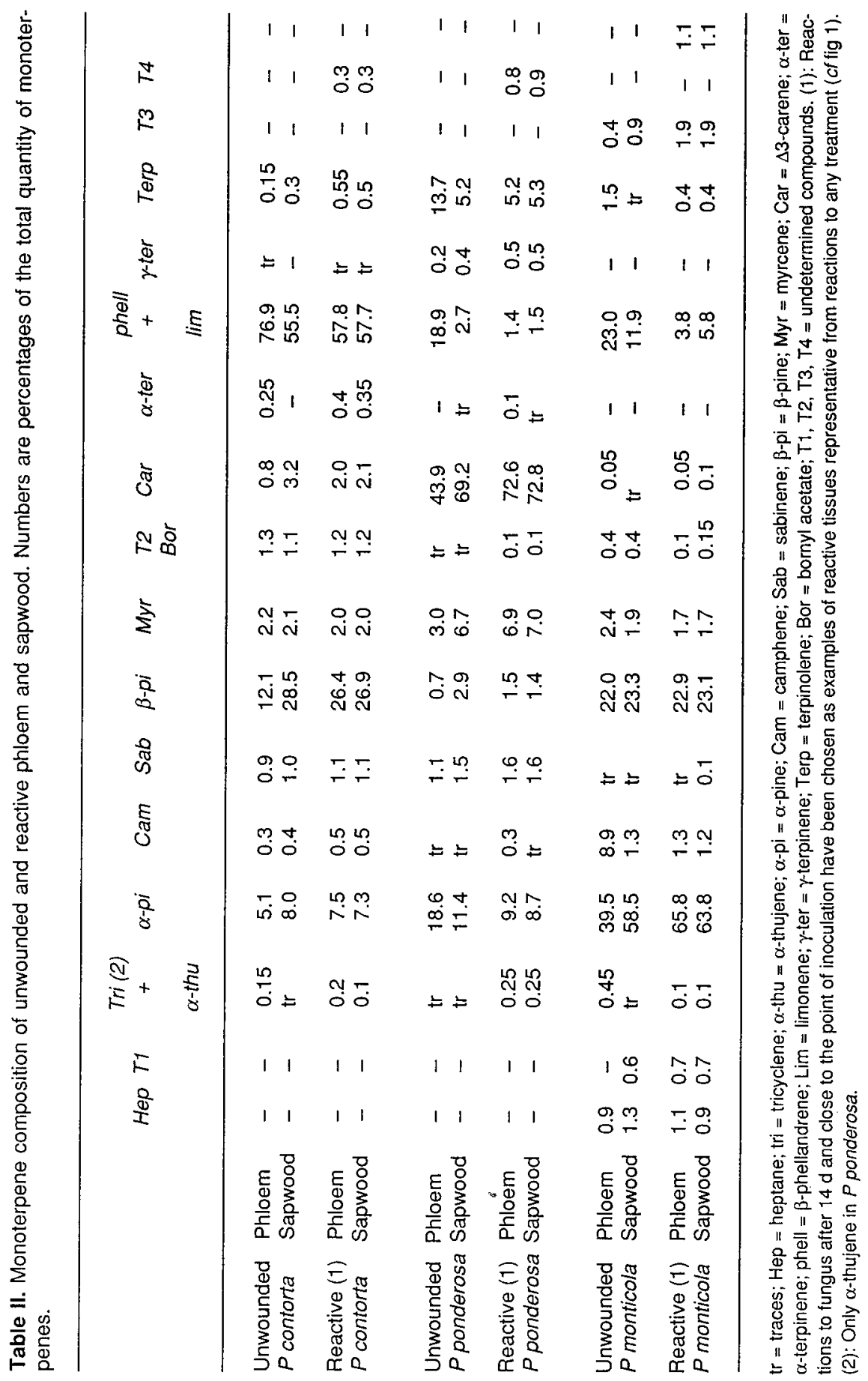



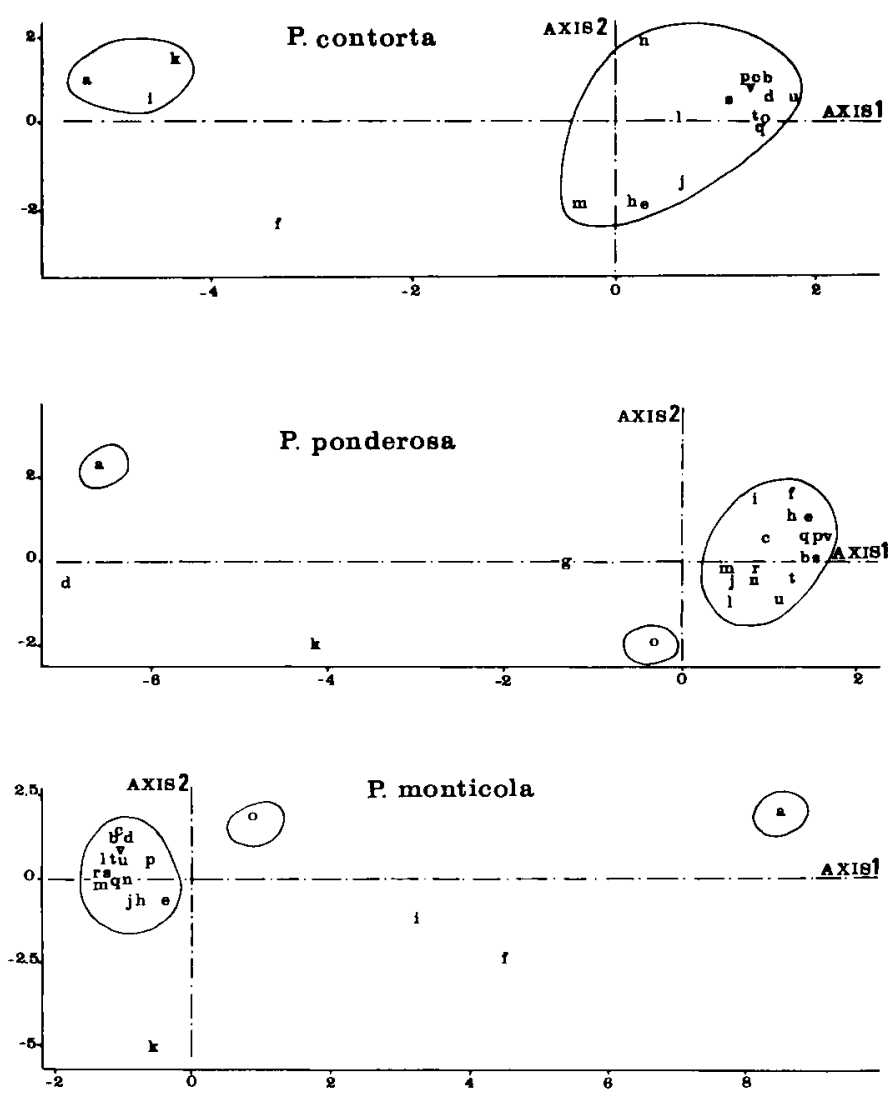

Fig 1. Comparison of the monoterpene composition of the different samples by principal component analysis (PCA). Only monoterpenes with a maximum ratio of at least $0.5 \%$ were considered. Circles around "clusters" were drawn by hand. $a=$ unwounded phloem; $b, c, d$, = reactive phloem $14 \mathrm{~d}$ after treatment by $O$ clavigerum at respectively $10-20,20-40$ and $40-60 \mathrm{~mm}$ from the point of injury; $\mathrm{e}, \mathrm{f}, \mathrm{g}$ $=i d e m$ after treatment by chitosan; $\mathrm{h}, \mathrm{i}=$ reactive phloem $14 \mathrm{~d}$ after treatment by PIIF at respectively 0-20 and 20-40 mm from the point of injury; $j, k=i d e m$ after treatment by buffer control; $l, m, n=$ reactive phloem at $0-20 \mathrm{~mm}$ from the point of injury $3 \mathrm{~d}$ after treatment by respectively $O$ clavigerum, chitosan and PIIF; $O=$ unwounded sapwood; $p, q, r, s=$ reactive sapwood $14 \mathrm{~d}$ after treatment by respectively $O$ clavigerum, chitosan, PIIF and control buffer; $t, u, v=$ reactive sapwood $3 \mathrm{~d}$ after treatment by respectively $O$ clavigerum, chitosan and PIIF. Note: in $P$ contorta, unwounded sapwood was separated from reactive tissues by the third axis.

in different tree species, except for $\beta$ phellandrene + limonene which always decreased. Some reactive phloem samples had a monoterpene composition similar to unwounded phloem (fig 1), but always in parts of the reaction most distant from the point of inoculation or injection; eg, PIIF (20-40 mm after $14 \mathrm{~d}$ ) and buffer (20-40 $\mathrm{mm}$ after $14 \mathrm{~d})$ from Lodgepole pine phloem. In addition to the 3 main types of 


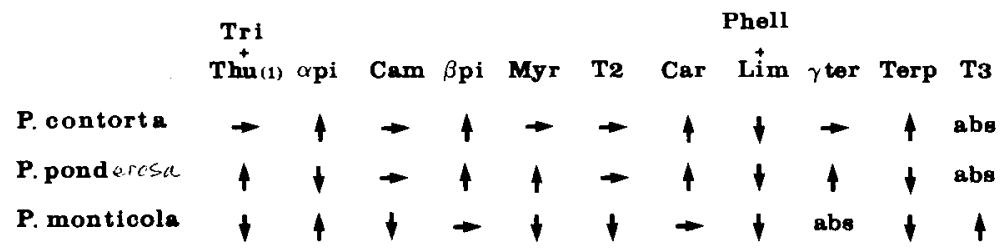

Fig 2. Comparative changes in monoterpene compositions of the phloem induced in 3 pine trees by a fungus inoculation after $14 \mathrm{~d}$, as an example of reactive tissues representative from reactions to any treatments (cf fig 1). This table is limited to those monoterpenes which varied in at least 1 tree. The monoterpene abbreviations are the same as those in table II. (1) Only $\alpha$-thujene in P ponderosa. Abs $=$ absent.

monoterpene composition, some phloem samples appeared intermediate between unwounded phloem and reactive tissues (fig 1). These also originated from parts of the reaction distant from the point of inoculation or injection; eg, chitosan $(20-40 \mathrm{~mm}$ after $14 \mathrm{~d})$ from Lodgepole pine, chitosan $(40-60 \mathrm{~mm}$ after $14 \mathrm{~d})$ and buffer $(20-40$ $\mathrm{mm}$ after $14 \mathrm{~d}$ ) from Ponderosa pine, chitosan (20-40 mm after $14 \mathrm{~d}$ ) and PIIF (20$40 \mathrm{~mm}$ after $14 \mathrm{~d}$ ) from Monticola pine. In these intermediate samples, the ratio of some monoterpenes was similar to that of unwounded phloem, the ratio of others was similar to that of reactive phloem, while others had a ratio intermediate between the 2 categories of phloem.

The fungus sample $(40-60 \mathrm{~mm}$ after 14 d) in $P$ ponderosa and the buffer sample (20-40 $\mathrm{mm}$ after $14 \mathrm{~d}$ ) in $P$ monticola were atypical, not being separated from unwounded or reactive phloems by axis 1 but by axis 2 . In fact, these 2 samples differed from their respective group by 1 terpene ( $\beta$-pinene in $P$ ponderosa and T3 in $P$ monticola) which had an "abnormally" high concentration.

In the case of $P$ contorta, it was possible to recognize 3 subgroups inside the reactive samples (fig 1). One consisted of all reactive sapwood and phloem samples resulting from fungus inoculation after $14 \mathrm{~d}$; these samples had the highest values along axis 1 . The 2 others included reactive phloem after $3 \mathrm{~d}$ or phloem treated by buffer, PIIF or chitosan, the value on axis 1 being lower than the previous subgroup. It was not possible, however, to recognize such subgroups in $P$ ponderosa and $P$ monticola.

\section{INTERPRETATION AND DISCUSSION}

\section{Comparison between treatments}

The increase in total monoterpenes (hydrocarbides) after treatment is in agreement with all previous results of phloem and sapwood reactions in different conifer species (Shrimpton, 1973; Russel and Berryman, 1976; Raffa and Berryman, 1982a, b; Schuck, 1982; Miller et al, 1986; Delorme and Lieutier, 1990). We observed differences in the responses of a given tree to fungus, chitosan, PIIF or buffer, the former quantitative treatment inducing a higher accumulation of resins. Chitosan induced a quantitative reponse comparable with that 
induced by the fungus, or higher than that induced by PIIF and buffer, only in some cases. Our results are thus not in a complete agreement with those of Miller et al (1986) and with our previous histological observations in suggesting a possible role of chitosan as natural elicitor of defensive metabolism in conifers (Lieutier and Berryman, 1988).

In considering the qualitative response, we note that situations where the monoterpene composition of the reactive tissues was similar to that of unwounded tissues or was intermediate, were all found in samples collected far from the point of aggression. This allows us to consider these situations as either outside the reaction or being an incomplete reaction. This opinion is strengthened by the fact that the total concentration of monoterpenes in these cases was similar to that of unwounded tissues. On the contrary, in situations close to the point of aggression, all reactions clearly differed qualitatively from unwounded phloem. Moreover, they all had the same qualitative composition. Each of the trees responded in a different way. However, we can conclude that the responding tissues of a given tree all have the same monoterpene composition irrespective of treatment, and that this composition differs from the unwounded tissues of the same tree.

The conclusion that the reaction is nonspecific for the agression supports the results of Cook and Hain (1985), with Loblolly pine and 2 strains of Ophiostoma minus, and of Delorme and Lieutier (1990) with Scots pine and 3 different fungi and 1 beetle species. In his histological studies, Mullick (1977) suggested that response to inju$r y$ is not in defense but rather to restore tissues and block sapwood conduction, processes which are inherent, and not specific as to the incitant. However, we need more information to suggest if such a hy- pothesis is the case after beetle- fungus attack.

This non-specificity, together with the fact that we found sterile phosphate buffer inducing the same qualitative response, make it difficult to prove the role of chitosan and PIIF as natural elicitors. Moreover, it favors the hypothesis that the elicitor originates from the tree. Nevertheless, Raffa and Berryman (1982a) found that monoterpene composition of the reaction of Abies grandis induced by inoculations with Trichosporium symbioticum Wright differed significantly from uninjured phloem in terms of many compounds, while the composition of the reaction to mechanical wounding differed significantly from unwounded phloem by only one compound. Thus the reaction to fungal inoculation was qualitatively different than to mechanical wounding. As a consequence, our results in pines do not agree with those of Raffa and Berryman (1982a) in firs.

\section{Comparison between tissues}

The monoterpene composition of reactive tissue was similar for phloem and for sapwood in all 3 species, but the composition of constitutive tissues was different. Thus, the reaction state of tissues can be characterized by a well-defined monoterpene composition in a particular tree, and this does not depend on the initial composition of the tissue. Shrimpton (1973) did not find significant qualitative changes in the sapwood of $P$ contorta in response to attacks by $D$ ponderosa. This is explained by the fact that reactive sapwood had a composition close to that of unwounded sapwood. Shrimpton (1973) only found an increase in $\beta$-phellandrene, which is contrary to our results, but this may be due to betweentree variation in the qualitative response, as observed by Schuck (1982) in the sap- 
wood of $P$ abies and by Delorme and Lieutier (1990) in the phloem of $P$ sylvestris.

The existence of a defined monoterpene composition of reactive tissues for a given tree, whatever the tissue, fits the hypothesis that neosynthesis is from cells different from those responsible for the synthesis of constitutive resin. This is in agreement with the ideas of Reid et al (1967), Berryman (1969), Cheniclet et al (1988) and Lieutier and Berryman (1988), who suggested that parenchymal cells were responsible for neosynthesis. Our results can be explained by the intervention of an elicitor whose "message" could be read by any target cell. Indeed, Cheniclet et al (1988) suggested that the neosynthesis against a beetle-associated fungus in Pinus pinaster is preceded by the reactivation of previously inactive cells.

\section{Comparison between trees}

In response to aggressors, each tree responded in a different manner. There were no between-tree similarities in the monoterpene response. Indeed, only one terpene varied in the same direction (decrease) in the 3 trees. The modification of the monoterpene ratio in response to $O$ clavigerum was thus different in each tree although they are all hosts of $D$ ponderosae and $O$ clavigerum.

Russel and Berryman (1976), Bordasch and Berryman (1977) and Raffa and Berryman (1982a) have reported that the defense reactions of $A$ grandis to $T$ symbioticum contain a higher relative concentration of the terpenes which are least favorable to Scolytus ventralis LeConte, the beetle associated with $T$ symbioticum. Conversely, the monoterpenes least repellent to this beetle decline in the defense reaction (Bordasch and
Berryman, 1977). In our experiments, however, the 3 pines did not exhibit a consistent differential response to $O$ clavigerum. Moreover, resistance of $P$ ponderosa to Dendroctonus brevicomis LeConte seems to be associated with limonene and myrcene concentrations (Smith, 1966); limonene is the most toxic monoterpene to this beetle, followed by $\Delta 3$-carene and myrcene (Smith, 1965). In our $P$ ponderosa samples, however, myrcene and $\Delta 3$ carene increased while limonene decreased. Raffa and Berryman (1982b) found that the percentages of $\alpha$-pinene and limonene increase while $\Delta 3$-carene decreases in the response of $P$ contorta to $O$ clavigerum while in our experiment concentrations of $\alpha$-pinene and $\Delta 3$-carene both increased. These results suggest that between-tree variability in monoterpene composition is the rule in the response of $P$ contorta, as is also true for $P$ abies (Schuck, 1982) and $P$ sylvestris (Delorme and Lieutier, 1990).

Consequently, the qualitative monoterpene response of conifers does not seem to be adapted to the species of aggressor. Instead, the role of monoterpene in the induced reponse of conifers to aggression is probably quantitative and dose-dependent, as previously suggested (Raffa and Berryman, 1982a, b; Delorme and Lieutier, 1990).

\section{ACKNOWLEDGMENTS}

This work was conducted as part of ACtion Thématique Programmée CNRS-INRA No 4320 . F Lieutier's visit to the USA was supported by a grant from the Ministry of Industry and Research of France. The authors thank $Y$ Hiratsuka, Northern Forest Research Centre, Edmonton, Alberta, Canada, LA Hadwiger of the department of plant pathology, and CA Ryan of the Institute of Biological Chemistry, Washington State University, Pullman, for kindly providing 
the $O$ clavigerum strain, chitosan, and PIIF, respectively. We also thank D Sauvard, INRA, Ardon, France, for his help in the treatment of the data.

\section{REFERENCES}

Berryman AA (1969) Responses of Abies grandis to attack by Scolytus ventralis (Coleoptera: Scolytidae). Can Entomol 101, 1033-1041

Berryman AA (1972) Resistance of conifers to invasion by bark beetle-fungus associations. Bio Science 22, 599-601

Bordasch RP, Berryman AA (1977) Host resistance to the fir engraver beetle, Scolytus ventralis (Coleoptera: Scolytidae). 2. Repellency of Abies grandis resins and some monoterpenes. Can Entomol 109, 95-100

Cates RG, Alexander H (1982) Host resistance and susceptibility. In: Bark Beetles in North American Conifers (Mitton JB, Sturgeon, KB eds). Univ Texas Press, Austin, 212-263

Cheniclet C, Bernard-Dagan C, Pauly G (1986) Terpene biosynthesis in pathological conditions. In: Mechanisms of Woody Plant Defenses Against Insects; Search for Pattern (Mattson WJ, Lévieux J, Bernard-Dagan C eds) Springer, 117-130

Cook SP, Hain FP (1985) Qualitative examination of the hypersensitive response of Loblolly pine Pinus taeda $\mathrm{L}$, inoculated with two fungal associates of the southern pine beetle, Dendroctonus frontalis Zimmermann (Coleoptera: Scolytidae). Environ Entomol 14, 396-400

Delorme L, Lieutier F (1990) Monoterpene composition of the preformed and induced resins of Scots pine, and their effect on bark beetles and associated fungi. Eur J For Pathol 200, 304-316

Green TR, Ryan CA (1972) Wound-induced proteinase inhibitor in tomato leaves. Plant Physiol 51, 19-21

Hadwiger LA, Beckman JM (1980) Chitosan as a component of pea-Fusarium solani interactions. Plant Physiol 66, 205-211

Hadwiger LA, Beckman JM, Adams MJ (1981) Localization of fungal components in the pea-Fusarium interaction detected immunochemically with anti-chitosan and anti-fungal cell wall antisera. Plant Physiol 67, 170-175
Lieutier F, Berryman AA (1988) Preliminary histological investigations on the defense reactions of three pines to Ceratocystis clavigera and two chemical elicitors. Can J For Res 18 , 1243-1247

Miller RH, Berryman AA, Ryan CA (1986) Biotic elicitors of defense reactions in Lodgepole pine. Phytochemistry, 25, 611-612

Mullick DB (1977) The non-specific nature of defense in bark and wood during wounding insect and pathogen attack. In: Recent $A d-$ vances in Phytochemistry. Plenum Press, Vol 2, 395-441

Raffa KF, Berryman AA (1982a) Accumulation of monoterpenes and associated volatiles following inoculation of grand fir with a fungus transmitted by the fir engraver, Scolytus ventralis (Cloleoptera: Scolytidae). Can Entomol $114,797-810$

Raffa KF, Berryamn AA (1982b) Physiological differences between Lodgepole pines resistant and susceptible to the mountain pine beetle and associated microorganisms. Environ Entomol 2, 486-492

Raffa KF, Berryman AA (1983) The role of host resistance in the colonization behavior and ecology of bark beetles (Coleoptera: Scolytidae). Ecol Monogr 53, 27-49

Reid RW, Whitney HS, Watson JA (1967) Reactions of Lodgepole pine to attack by Dendroctonus ponderosae Hopkins and blue stain fungi. Can J Bot 45, 1115-1126

Russel CE, Berryman AA (1976) Host resistance to the fir engraver beetle. 1. Monoterpene composition of Abies grandis pitch blisters and fungus-infected wounds. Can $J$ Bot 54, 14-18

Ryan CA, Bishop PD, Walker-Simmons $M$, Brown WE, Graham JS (1985) Pectic fragments regulate the expression of proteinase inhibitor genes in plants. In: Cellular and Molecular Biology of Plant Stress. AR Liss, 319334

Safranyk L, Shrimpton DM, Whitney HS (1975) An interpretation of the interaction between Lodgepole pine, the mountain pine beetle, and its associated blue stain fungi in western Canada. In: Management of Lodgepole Pine Ecosystems (Baugmartner DM ed) Coop Ext Serv, Wash State Univ, Pullman 406-428

Schuck HJ (1982) The chemical composition of the monoterpene fraction in wounded wood 
of Picea abies and its significance for the resistance against wound infecting fungi. Eur $J$ For Pathol 12, 175-181

Shrimptom DM (1973) Extractives associated with the wound response of Lodgepole pine beetle and associated micro-organisms. Can $J$ Bot 51, 527-534

Shrimpton DM (1978) Resistance of Lodgepole pine to mountain pine bettle infestation. In: Theory and Practice of Mountain Pine Beetle Management in Lodgepole Pine Forests (Berryman AA, Amman GD, Stark RW, Kibbee DL, eds) College of For Resources, Univ Idaho, Moscow, ID, 64-76

Smith RH (1965) Effect of monoterpene vapors on the western pine beetle. $J$ Econ Entomol $58,509-510$

Smith RH (1966) The monoterpene composition of Pinus ponderosa xylem resin and of Dendroctonus brevicomis pitch tubes. For Sci 12, 63-68
Smith RH (1983) Monoterpene of Lodgepole pine xylem resin: a regional study in the western United States. For Science 29, 333340

Walker-Simmons $M$, Jin D, West CA, Hadwiger L, Ryan CA (1984) Comparison of proteinase inhibitor inducing activities and phytoalexin elicitor activities of pure fungal endopolygalacturonase, pectic fragments and chitosans. Plant Physiol 76, 833-836

Wong BL, Berryman AA (1977) Host resistance of the fir engraver beetle. 3. Lesion development and containment of infection by resistant Abies grandis inoculated with Trichosporium symbioticum. Can J Bot 55, 2358-2365

Wright $E$ (1933) A cork-borer method for inoculating trees. Phytopathology 23, 487-488

Zavarin E, Snajberk K, Critchfield WB (1977) Terpenoid chemosystematic studies of Abies grandis. Bioch Syst Ecol 5, 81-93 